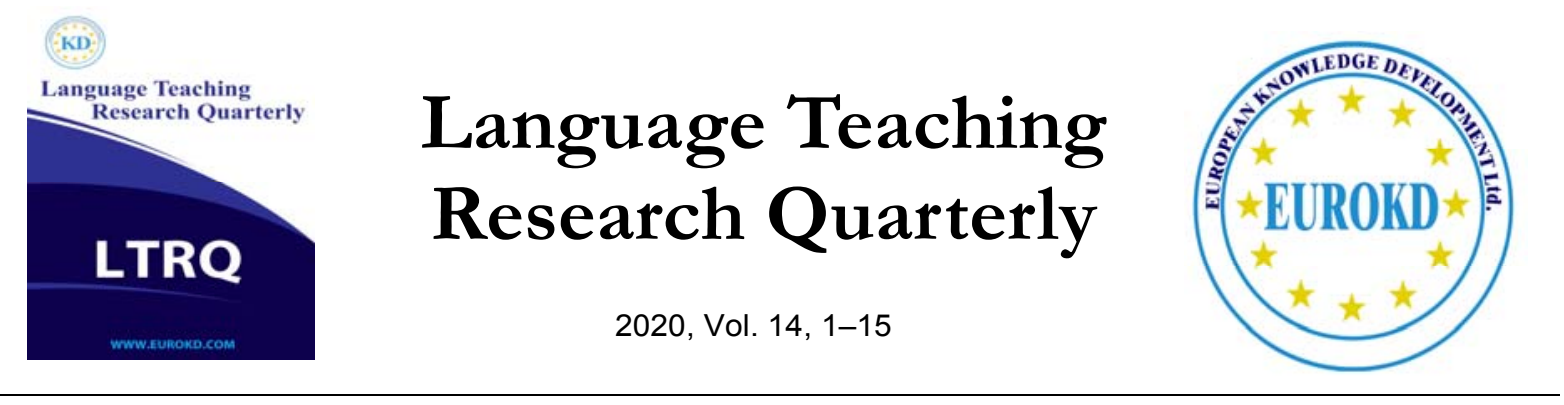

\title{
The Relationship between the Reported Reading Anxiety Level and Reading Strategy Use of Iranian Elementary Level EFL Learners
}

\author{
Shabnam Mokhtarnia, Nasrin Ghaffarzadeh* \\ Danesh-e-Alborz University of Qazvin, Qazvin, Iran
}

Received 03 June 2019 Accepted 11 November 2019

\begin{abstract}
Reading is an essential skill for second and foreign language learners. It is the heart of all formal learning. Students 'success or failure in reading at early grades resonates throughout the rest of their lives. The purpose of this study is to investigate the relationship between reading anxiety and reading strategy use of Iranian elementary level EFL learners. The participants of this study were fifty students with the age range of 14 to 28 years old, both from female and male of Iranian EFL elementary learners from Beynolmelal English language institute in Tehran. The research design of this study was quantitative. In order to collect data two basic instruments were administered to the participants. The first instrument was a questionnaire that was administered to investigate the participants' level of reading anxiety. The second questionnaire was in addition used to examine the participants' reading strategy use The first questionnaire was composed of 20 items which were rated by a five-point Likert scale, ranging from five point (strongly agree) to one point (strongly disagree). The second questionnaire consisted of 30 items similarly rated on a five-point Likert scale, ranging from one point (I never or almost never do this) to five points (I always or almost always do this). The correlation coefficient between the reading anxiety and reading strategy use would be determined out with the assistance of IBM SPSS. The findings of this study would be expected to give valuable information to English teachers and material developers to recognize the elementary level learners' anxiety level and improve their reading strategy use in language classes.
\end{abstract}

Keywords: Reading Strategy, Language Learning, English Language, Reading Anxiety

\section{Introduction}

Studies on L2 reading over the past few decades have demonstrated that reading is a vital source of input; although, it is also an anxiety stimulating activity (Saito, Horwitz, \& Garza,1999). 
Among different affective variables which could influence the process of second language learning, anxiety poses significant problems in the cognitive process of learning (Ahmad \& Zafar, 2010; Horwitz \& Young, 1991; Sellers, 2000; Sharma \& Gandlhi, 1971). Strategies for language learning and language use in addition have been receiving remarkable attention in the areas of foreign language teaching and learning (Cohen, 1990; Oxford, 1990; Wenden, 1991). Reading strategiesare considered as one of the attributes of cognitive psychology which are necessary for successful comprehension (May, 2001; Walker, 2000; Zare, 2013). Correspondingly, these strategies have been described by Cohen (1990) as mental processes that readers ceaselessly select to utilize to accomplish reading tasks successfully or as " techniques and procedures readers utilize to make their reading successful" (Baker \& Boonkit, 2004, p.302). In addition, reading strategies have been defined as plans and behaviors for unraveling problems when faced in constructing meaning (Janzen, 2003). Language learning strategies are described as particular functions purposely employed by the students for the goals of learning language (Yang, 2006). Previous research shows that successful and less successful readers utilize various reading strategies, and that factors such as age, learning style, anxiety, and so on can affect students' use of learning strategies in reading comprehension (Yang, 2006).

On the other hand, anxiety plays a significant role in foreign language learning exclusively in the learning of additional languages (Saito \& Samimy, 1996; Samimy \& Tabuse, 1992). To the knowledge of the researchers, the present study is one of the few studies which focuses on the relationship between reading anxiety and reading strategy use of EFL students in Iran. The study can be significant inproviding insights into reading strategies employed by Iranian elementary level EFL learners to facilitate their reading process.

There are many studies (e.g., Horwitz; Horwitz \& Cope, 1986; Ellis, 1994; Brown, 2000, Macintye \& Gardner, 1991) that have been worked to explore the learners' anxiety level of reading. Since, there is a lack of study involving both reading anxiety and reading strategy use, this study aims to examine the relationship between reading anxiety a dreading strategy use of Iranian elementary level EFL learners. The findings of this study could also be of great importance to language teachers, teacher trainers, material developers as this study could provide valuable information to recognize the importance of the relationship between thelanguage learner's anxiety leveland their reading strategy use.

\section{Review of the Related Literature}

One of the superior importance in all ELT texts is a second language reading comprehension skill. Harris and Hodges (1995) noticed that researchers are split between those who feel a comprehender's mental representation which must be in accordance with that intended by the author (the perspective adopted in the current study), and those from a more literary bent (e.g., Lee, 2001). According to Ediger (2002), the use of basic texts in classroom has been a general method in teaching reading. Edigar (2002) recognizes that the use of basic texts in classrooms has been a common method in teaching reading. This is very commutable for teachers because the teacher's manual can be used in part as the teachers chooses. In the Psychology of Reading 
Instruction, Edigar illustrates, "The content may become too easy which can make for boredom or a lake of interest, nor should it be complex making for pupil failure" (2002, p.3).

\section{Reading Strategies}

Reading strategies are necessary for prospering comprehension as one of the features of cognitive psychology (May, 2001; Walker, 2000; Zare, 2013). In addition, reading strategies have been identified as reflections and treatments for unraveling problems when faced in constructing meaning (Janzen, 2003) that reading strategy as a supersensible action that readers purposely choose to utilize to thorough reading task successfully. Furthermore, reading strategiesare defined as "techniques and methods readers use to make their reading successful" (Baker \& Boon kit. 2004, p.302). Brandmeier (2002) reminds us, reading strategies are: "the e: a study of learner anxiety in beginning, intermediate, and advanced what they read" (p.1): they they are determined as processes, deeds, and proceedings used to improve reading comprehension. Reading strategies include reading loudly, exegesis, hypothesis, guessing rereading the passage, maintaining the information asking questions, interpreting and using a dictionary (Brandmeier, 2002). The prosperous utilize of reading strategy affairs learners reading comprehension (Huang, Chern, \& Lin, 2009).

\section{Foreign Language Anxiety}

Anxiety is correlated with some adverse tending such as: nervousness, uneasiness, self- doubt, concern, agonize and its extreme fear (Rachman, 2004; Mukminin, Muazza, Hustarna, \& Sari, 2015; Mukminin, Ali, \& Fadloan, 2015; Mukminin, Noprival, Masbirorotni, Sutarno, Arif \& Maimunah, 2015). Foreign language anxiety negatively affects foreign language performance, Although, it has been classified into three types: state, trait and situational (Spielberger,1983). State anxiety is the fright which a person experiments at a specific moment in time as a replication to a definite condition. Trait anxiety is defined as an individual's liability of becoming nervous any situation (Spielberger, 1983). Trait anxiety is typically viewed as an aspect pf personage. Situational anxiety is the particular forms of anxiety which happen coherently over time interior a given condition (MacIntyre \& Gardner, 1991a).

It is commonly accepted that foreign language anxiety is a form of situation- specific anxiety and is distinctive from other types of general anxiety (Aida, 1994; Horwitz et al., 1986; MacIntyre \& Gardner, 1991b, 1991c, 1993). Foreign language anxiety has been pinpointed as diverse from other types of anxiety and is special to the foreign language learning situation (MacIntyre\& Gardner, 1989; 1991;1991b)."The research into the connection of anxiety to foreign language learning has provided mixed and confusing results, immediately suggesting that anxiety itself is neither a simple nor well-understood psychological construct" (p.132).

Horwitz et al. (1986) replied to the fact that researchers had"neither adequately defined foreign language anxiety nor described its specific effects on foreign language learning" (p.125) and identified foreign language anxiety as "a distinct complex of self-perceptions, beliefs, 
feelings and behaviors related to classroom language learning arising from the uniqueness of the language learning process" (p.128).

A considerable amount of literature had maintained a study to investigate the existence of anxiety in foreign language learning. Lots of foreign language learners experience foreign language anxiety as "a situation- specific and unique type of anxiety closely related to the acquisition of foreign language" (Horwitz, Horwitz, \& Cope, 1986, p.125). Brown (1994) argued that anxiety can usually act as a useful energizer for L2 learning, and the negative effect cannot be easily neglected in the context of L2 teaching. A large and growing body of literature have stationed on foreign language anxiety in this field. All four skills of foreign language learning, for instance; reading, writing, listening, and speaking, were contained beneath the notion of FLA (Casado \& Dareshiwsky, 2004; Cheng, 2004; Horwitz, 1986; Horwitz, 2001; Sanchez-Herrero \& Sanchez, 1992). Research on language anxietyhas confirmed a feasible relation between anxiety and performance, and its interposition in language competence (Horwitz, Horwitz \& Cope, 1986; MacIntyre \& Gardner, 1989; Sellers, 2000). Horwitz et al. (1986) mentioned that learner's reliance and self-confidence may affected by foreign language anxiety. Many anxious learners may not summon matter learned before (Horwitz et al., 1986; Sellers, 2000). Also contrasted to learners who are less solicitous, may be less energetic in the classroom (Horwitz et al., 1986). A large amount of studies in a matter of fact has demonstrated that foreign language anxiety has a quite harmful effect on the learning procedure and efficiency (Horwitz et al., 1986; MacIntyre \& Gardner, 1989; Sellers, 2000; Young, 1991).

\section{Reading Anxiety}

Numerous studies (Gardner, 1985; Horwitz, 1986) on language learning and learning anxiety has demonstrated that anxiety is an essential variable in second and foreign languagelearningwith adults, but not so with children. As noted by Horwitz et al. (1986) "Reading anxiety is a particular type of anxiety from the more general types of foreign language anxiety that has been linked to oral performance" (p.215). Yamashita (2004) suggested that anxiety in reading was premieres in L2 than L1 and self-conception as reader was more affirmative in L1 more than L2 among EFL learners. Saito et al., (1999) mentioned that foreign language reading anxiety level was related to peculiar target language and it diverse by target language. Although several studies (e.g., Huang, 2001; Saito et al., 1999; Shi \& Liu, 2006; Zhang, 2000) have represented that foreign language reading anxiety exists amidst foreign language learners, some other researches demonstrate that foreign language reading anxiety is not much of a worry to progressed language learners and foreign language reading anxiety level is linked to the comprehend difficult level of the reading substance and following reading tasks (Brantmeier, 2005). Some studies (Abu-Rabia, 2004; Brantmeier, 2005) in addition indicate that reading affords less anxiety than other functions or language sills among foreign language learners that's why readers can utilize reading strategies to help comprehension. The results of such studies demonstrates that FL reading anxiety really exists and differs from general FL anxiety and varies to the target language reading (Saito et al., 1999; Kuru-Gonen, 2007). 


\section{Purpose of the Study}

The purpose of this study was to investigated the relationship between reading anxiety and reading strategy use of Iranian elementary EFL learners. Reading is a procedure that we utilize to gather information for some intention. Goodman (1994) noted that reading inducts connecting in a significant way to the project we have and predicting novel meaning from previous experiences. Readers can use some strategies with which they feel convenient when they understand the information and reply to it as they interact with the language of a text. According to Lien (2011) it is an efficient way to find a solution annoyed by learners while reading academic material. In truth, many students do not know what the actualaim of reading is. This study attempted to investigate between reading anxiety and reading strategy use of Iranian elementary level EFL learners.There have been several studies that investigated the relationship between motivation and reading anxiety.However, little attention has been paid to the relationship between reading anxiety and reading strategy use, more particularly in the EFL context of Iran.

\section{Research Question}

The research question which was raised in this study is as follows:

RQ: Is there any statistically significant relationship between the reported reading anxiety level and reading strategy use of Iranian elementary level EFL learners?

\section{Research Hypothesis}

The research hypothesis which was raised in this study is as follows:

RH: There is not any statistically significant relationship between the reported reading anxiety Level and reading strategy use of Iranian Elementary Level EFL learners.

\section{Methodology}

This study was a correlation research in the term of quantitative design. A correlational research investigates the possibility of the relationship between two or more than two variables. This study was conducted to explore the relationship between reading anxiety and reading strategies use that employed by Iranian EFL Elementary level. Quantitative methods of data collection and analysis were employed for the current study. The participants of this study were fifty female and male Iranian EFL elementary learners from Beynolmelal English language institute in Tehran with the age range of, 14 to 28 years old.

\section{Instrumentation}

In order to collect data two basic instruments were administered to the elementary level EFL learners in different classes. The first instrument was a questionnaire that was designed by Saito, Horwitz, and Gorzo (1990) which was administered to investigate the participants' level of reading anxiety. Furthermore, the second questionnaire was SORS whichwas designed by Sheorey and Mokhtari (2001). It was used to examine the participants'reading strategy use which 
included three categories. The first one was Global Strategies that could aid readers to control and operate their reading through the passage in the classroom; the second one was Problem Solving Strategies which could help learners to discover and unravel suitable answer to questions. The third group was Support Strategies which could help readers to improve their questions and aid them to have opportunity to solve their problems, and propagate their reading comprehension in order to have a better understanding from the passage.

\section{Procedure and Data Analysis}

The design of this research was quantitative and it explored the relationship between reading anxiety and reading strategy use employed by Iranian elementary level EFLlearners. To this end, two questionnaires wereadministered to the students, and the participants were asked to complete them carefully.in order to collect data, the foreign language anxiety scale (FLRAS) developed by Saito et al. (1999) was used to assess students' level of reading anxiety. The questionnaire was composed of 20 items which were rated by a five-point Likert scale, ranging from five point (strongly agree) to one point (strongly disagree). The second questionnaire which was developed by Mokhtari and Sheory (2001), consisted of 30 items on a five-point Likert scale, ranging from one point (I never or almost never do this) to five points (I always or almost always do this). In order to investigate the relationship between the reading anxiety and reading strategy use of the participants, which was the main purpose of this research, the statistical technique of correlational analysis was carried out with the assistance of IBM SPSS.

\section{Results}

In this section the results of the statistical analysis of the collected data are presented in detail.

Table 1

Test of Normality

\begin{tabular}{|c|c|c|c|c|c|c|}
\hline \multirow[b]{3}{*}{ Reading anxiety } & \multicolumn{3}{|c|}{ Shapiro-Wilk } & \multicolumn{3}{|c|}{ Kolmogorov-Smirnov } \\
\hline & significant & off & statistic & significant & off & atistic \\
\hline & .205 & 50 & .969 & $.200 *$ & 50 & 072. \\
\hline Reading strategy & .100 & 50 & .961 & $.200 *$ & 50 & .096 \\
\hline
\end{tabular}

Table1 demonstrates the test of normality of the data. In Table 1 the results of Kolmogorovsmirnov test between the reading anxiety and the reading strategy have shown that all of the data were not significant (significant $=.2000$ ), it means that whole of the data have normally distributed. 
Table 2

Descriptive Statistics of the Instruments

\begin{tabular}{lcccccc}
\hline & Age & $\begin{array}{c}\text { Reading } \\
\text { anxiety }\end{array}$ & $\begin{array}{c}\text { Reading } \\
\text { strategy }\end{array}$ & $\begin{array}{c}\text { Global } \\
\text { strategy }\end{array}$ & $\begin{array}{c}\text { Supporting } \\
\text { strategy }\end{array}$ & $\begin{array}{c}\text { Problem solving } \\
\text { strategy }\end{array}$ \\
\hline Number & 50 & 50 & 50 & 50 & 50 & 50 \\
\hline Mean & 17,02 & 58,44 & 104,673 & 43 & 31,6735 & 30,3469 \\
\hline Standard division & 4,342 & 7,6840 & 16,6850 & 7,20243 & 5,53921 & 6,16290 \\
\hline
\end{tabular}

Table 2 demonstrates the descriptive statistical analysis of this study. As can be seen inTable1, the mean of the age was 17.02 and the mean of reading strategy use was $M=104.673$ $(\mathrm{SD}=16.6)$ which was higher than the mean of reading anxiety level $(\mathrm{M}=58.44 ; \mathrm{SD}=7.68)$. Global strategy use hadthe highest mean among the subcategories of reading strategies $(M=43$; $\mathrm{SD}=7.20$ ), it means that the participants tended to use Global Reading Strategies more frequently to monitor and manage their reading process.

Table 3

Descriptive Statistics of both Instruments in Terms of Gender

\begin{tabular}{lcccc}
\hline & \multicolumn{2}{c}{ Reading anxiety } & \multicolumn{2}{c}{ Reading strategy } \\
\hline Male & mean & Standard division & mean & Standard division \\
\hline Female & 61,14 & 7,79 & 99,64 & 17,34 \\
\hline
\end{tabular}

Table 4

Descriptive Statistics of the Subcategories of Reading Strategy Usein Terms of Gender

\begin{tabular}{lcccccc}
\hline & \multicolumn{2}{c}{ Global strategy } & \multicolumn{2}{c}{ Supporting strategy } & \multicolumn{2}{c}{ Problem solving strategy } \\
\hline & Mean & St. deviation & Mean & St. deviation & Mean & St. deviation \\
\hline Male & 42,07 & 6,99 & 29,93 & 5,17 & 27,86 & 7,24 \\
\hline Female & 43,37 & 7,35 & 32,37 & 5,60 & 31,34 & 5,48 \\
\hline
\end{tabular}

Table 3 and Table 4 demonstrate that the mean rank and standard deviation of males (Mean=61.14, $\mathrm{SD}=7.79$ ) was higher than the mean rank of female (Mean=57.37, $\mathrm{SD}=7.78$ ). In addition, the mean rank and standard deviation of reading strategies of female (Mean=106.69, $\mathrm{SD}=16.23$ ) was higher than the mean and standard deviationof male (99.64, $\mathrm{SD}=17.34)$. It means that females seemed to be less anxious than males and they tended to use more reading strategies than females. Furthermore, females tended to use more reading strategies from all of subcategories of reading strategies than males. (Global strategies $=$ Male $=42.07, \mathrm{SD}=6.99$; Female $=43.37, \mathrm{SD}=7.35$ ), (Supporting strategies: Male=29.93, $\mathrm{SD}=5.17$; Female=32.37, $\mathrm{SD}=$ 5.60), (Problem solving: Male $=27.86, \mathrm{SD}=7.24 ;$ Female $=31.34, \mathrm{SD}=5.48$ ). 
Table 5

Pearson Correlation between Reading Anxiety and Reading Strategy Use

\begin{tabular}{lr} 
Correlation & .242 \\
\hline Significant & .094 \\
\hline Number & 49
\end{tabular}

In Table 5, the results of Pearson Correlation Analysis between the FLRAS and the SORS, do not show any significant relationship (correlation $=0.242$, P 0.05). It means that there was no statistically significant relationship between the reading anxiety and reading strategies use of Iranian elementary level EFL learners.

Table 6

Correlation Matrix of the Subcategories of Reading Strategy Use and Reading Anxiety

\begin{tabular}{llcccc}
\hline & & Reading anxiety & Global & Supporting & Problem solving \\
\hline Reading anxiety & Correlation & 1 & & & \\
\hline Global & Correlation & .269 & 1 & & \\
\hline Supporting & Correlation & .091 & .766 & 1 & 1 \\
\hline Problem solving & Correlation & .247 & .544 & .666 & \\
\hline
\end{tabular}

The results of Table 6 demonstrate the correlation matrix of reading anxiety with subcategories of reading anxiety that in which we can see that there was not any statistically significant relationship between the reading anxiety and the subcategories of reading strategies.

\section{Discussion}

In the Iranian setting, reading plays an essential and effective role due to lack of exposure to English language inside and outside of the classroom. In many language education settings, students obtain more chances to read rather than to listen, speak or write in English. One of the major variable in these studies have been EFL learners' use of reading strategy in language learning and language use that has been receiving considerable attention in the field of foreign language teaching and learning (Cohen, 1990; O' Malley \& Chamot, 1990; Oxford, 1990; Wenden, 1991). In the field of applied linguistics, the term strategy has been one of the important and difficult terms to be defined, measured and classified because of the intricacy which exists in its matter. Some scholars have described strategy as conscious and subconscious mental processes which are utilized by students in language learning, language use and in language testing situations (Chamot et al., 1990). One of the features of cognitive psychology are reading strategies which are necessary for successful comprehension. (May, 2001; Walker, 2000; Zare, 2013). Accordingly, as a mental process these strategies have been described by Cohen (1990) that readers consciously choose to utilize to complete reading tasks successfully or as " procedures and techniques readers utilize to construct their reading successful" (Baker \& Booknit, 2004, p.302). Language teachers in many different contexts have been investigating ways to aid learners become more prosperous in their works to learn and communicate in foreign 
languages. The usage of language learning strategies is viewed as one vehicle for cultivating greater success. A strategy is considered to be "impressive" if it provides affirmative support to the learners in their efforts to learn or utilize the foreign language (Cohen, Weaver, \& $\mathrm{Li}$,1996). Another major variable of present study was reading anxiety that many studies have investigated foreign language reading affective variables such as anxiety which could be important contributing factors in the reading performance language learners (Saito, Horwitz, \& Garza, 1999; Sellers, 2000). According to Saito et al., (1998), foreign or second language reading might seem at first glance less affected by foreign language anxiety; yet many students have experienced reading-related anxiety, that can lead to poor reading comprehension. Recent study in the field of foreign language anxiety (FLA) has demonstrated that each skill has its own anxiety such as foreign language reading anxiety (FLRA) (Kuru-Gonen, 2005). Anxiety poses major problems in the cognitive process of learning among other different important variables (Ahmad \& Zafar, 2010; Horwitz \& Young, 1991; Sellers, 2000; Sharma \& Gandhi, 1971). According to Bernhardt (1991) research studies of Iranian EFL learners have proposed that the unproductive reading process could lead to reading anxiety from the socio-cognitive perspective of second language reading. The review of relevant literatures demonstrates that although foreign language anxiety has been revealed to have a negative correlation with foreign language reading performance, the relationship between foreign language reading anxiety and foreign language reading strategies has not been clearly established. The research question of this study asked whether there was any statistically significant relationship between the reported reading anxiety level and reading strategy use of Iranian elementary level EFL learners. In order to collect data to investigate the relationship between the reading anxiety and reading strategy use of Iranian elementary level EFL students, two basic instruments which were translated to their mother tongue (Persian) were given to the participants in different classes. The first instrument was a questionnaire that was designed by Saito, Horwitz, and Gorzo (1990) which was administered to investigate the participants' level of reading anxiety. Furthermore, the second questionnaire, SORS, was designed by Sheorey and Mokhtari (2001). It was used to examine the participants' reading strategy use which included three categories. The first one was Global Strategies that could aid readers to control and operate their reading through the passage in the classroom, it means that they could monitoring and managing their reading themselves in the process of reading comprehension. The second one was Problem Solving Strategies which could help learners to discover and unravel suitable answer for solving their problems, and the third one was Support Strategies which could help readers to improve their questions and it can aid them to have opportunity to solve their problems, and propagate their reading comprehension in order to have a better understanding from the passage. The design of this research was quantitative and it explored the relationship between reading anxiety and reading strategy use employed by Iranian EFL elementary levels. At this phase, two questionnaires were given to students; then, the participants were asked to complete them carefully. In order to collect data, foreign language anxiety scale (FLRAS) developed by Saito et al. (1999) was used to recognize students' level of reading anxiety. The first questionnaire was composed of 20 items which were rated by a five- 
point Likert scale, ranging from five point (strongly agree), four (disagree), three (neutral), two(agree), and one point (strongly disagree).The second questionnaire that was developed by Mokhtari and Sheory, consisted of 30 items on a five-point Likert scale, ranging from one point (I never or almost never do this), two (I do this just occasionally), three (I sometimes do this), four (I usually do this), and five points (I always or almost always do this).In order to investigate the relationship between the reading anxiety and reading strategy use of the participants, which was the main purpose of this research, the descriptive statistics (including mean, standard deviation, and frequency), and the statistical technique of correlational analysis Pearson product (Pearson product moment coefficient) was carried out with the assistance of IBMSPSS. First of all, the outliers of the data were checked out and then the normality of the whole data was explored to investigate whether our data was normal or not. After the evaluation of the data, the results demonstrated that all of our data were normal; it means that we could use Pearson product moment correlation, not spearman's correlation analysis which is a non-parametric alternative of this statistical procedure. Furthermore, the present study was attempt to develop into the reading strategies used by EFL students and the components they deemed essential for a successful reading comprehension. Also, this study investigated the relationship between reading anxiety level and reading strategies use of elementary level EFL learners. The results of this research in line with the previous studies demonstrate that reading strategies are an essential part of reading process that is inseparable during the reading texts. In addition, this fact is made obvious in the reading models such as vocabulary, topical knowledge and genre, structure and reading techniques and grammar that are important factors in the reading passages. Besides, the results of SORS demonstrated that Elementary level EFL learners of Beynolmelal learners in Tehran were aware of their reading strategies. The majority of the participants were high users, which meant that they almost always used reading strategies while reading comprehension materials. The plausible explanation to support this finding is that's why they have been trained and exposed to use different reading strategies during the process of reading comprehension. Also, the participants experienced in learning English make them as affective strategies users. On the other hand, the results of FLRAS revealed that the level of reading anxiety of elementary level EFL learners of Beynolmelal institute in Tehran was medium anxiety readers. The participants' explanation to support this finding is that these participants had been engaged in English reading passages before administered the FLRAS questionnaire. Furthermore, they are already accustomed to the types of tasks given by the teacher during the reading parts. For this reason, totally they may not feel highly anxious any more when they face various reading texts. Although, the results of reading anxiety between male and female have showed that the mean rank and standard deviation of reading strategies of female (Mean=106.69, SD=16,23) was higher than the mean and standard deviation of male $(99.64, \mathrm{SD}=17,34)$. It meant that females seemed to be less anxious than males and they tended to use more reading strategies than females in the process of reading based on the result of Pearson product moment correlations, it was found that students' reading anxiety did not relate to their reading strategies use. The finding indicated $\mathrm{r}$ correlation coefficient was 0.242 (P 0.05). It means that there was no statistically 
significant relationship between the reading anxiety and reading strategies use of Iranian elementary level EFL learners. The conclusion shows that the higher participants' reading anxiety level does not guarantee the lower participants' reading strategies use. It may demonstrate an assumption that anxiety is not the only factor affecting students' reading strategies use. In 2014, Zarei mentioned that motivation levels have a comprehensive effect on students' reading strategies use. Likewise, the findings of Li (2010) illustrated that another factor is proficiency level which caused differences in both the type and frequency of reading strategy use. Additionally, there is another important factor that should not be neglected was the uncontrolled situation in which the questionnaires were completed. However, there is not much study on foreign language reading anxiety and reading strategy use confirm this findings of the study. The result of the present study was in accordance with Ghonsooly and Loghmani (2012). The similar result of this study is because they have the same major and level (i.e. senior English major students). Moreover, in 2014, Tramizi discovered that there was no correlation between reading anxiety level and reading strategies use. On the other hand, this finding was inconsistent with the result of Lien (2011) and Tsai (2013), which found there was a negative relationship between reading anxiety and reading strategy use. It means that the higher reading anxiety caused a few strategies are chosen by readers, or the more strategies learners use during their reading process, the lower learners' anxiety degreeis. Even though, the relationship exists, the degree of the relation is not strong sufficient. It can be seen that the negative relationship gained from this study because of the fact that the various learners of different levels. Hence, it is feasible which there might be real differences in their reading ability. At last, this study indicated that there was no statistically significant relationship between the reading anxiety and reading strategies use of Iranian elementary level EFL learners.

\section{Implications and Suggestions for Future Research}

The findings of this study have a number of vital implications for future practice. In addition to gaining a descriptive explanation of students' affective feeling when reading in a foreign language, the study attempted to address a particular research question concerned with the relationship between the participants' reading anxiety level and reading strategy use, measured through two specific questionnaires. The findings giveinsights into some valuable pedagogical implications for reading instruction. Even though reading seems at first glimpse the least anxietyarousing part of the EFL curriculum, the findings call for the recognition of the importance of foreign language reading anxiety and reading strategies.Similar to Horwitz's et al. (1986) propositions, there are several procedures that foreign language teachers can follow to aid reduce anxiety. Most specially, language instructors can help learners face with reading-related anxiety by preparing the learners for the probability of reading difficulties. Foreign language learners might be informed of the devitalizing effects of anxiety on their speaking within a communication context, however, they might not know that foreign language reading is also anxiety arousing. Foreign language teachers can raise students' awareness about the existence of anxiety in foreign language reading and let them realize that they are not lone when struggling 
with reading related anxiety.In addition, language teachers can give opportunity to learners to recognize their anxiety in order to face with it. Foreign language learners should be exposed to English texts with high readability level. That's why anxious students feel terrorized by English passages, filled with English letters (Lee,1999). Furthermore, language instructors should pay considerable attention to the choice of texts especially when utilizing culturally reliable texts. When reading texts containing culturally topics, language learners surely feel difficulty. There is an essential role here that belongs to language teachers; they should provide a wide variety of familiar cultural texts with an appropriate level of difficulty as an input to the language learners, and increase students' awareness about reading strategies. The results of this study propose that anxious students' reading processing is negatively intervened with task-irrelevant thoughts such as fear of negative assessment or self-concerns. Foreign language teachers should give students sufficient time to understand the text. As the finding represented, learners would feel disappointed and anxious when they understood they have insufficient time to understand the text. An exclusive concentration on time-reading activity should not be encouraged for anxious students till they can face with reading related anxiety,although timed-reading is an essential instruction for advanced learners to be fluent readers. In conclusion, anxiety is one type of emotional problem that could affect not only the language performance of learners but also their social life.

\section{References}

Abu-Rabia, S. (2004). Teachers' role, learners' gender differences, and FL anxiety among seventh-grade students studying English as a FL. Educational Psychology,24(5), 711721.http://dx.doi.org/10.1080/0144341042000263006

Ahmad Khan, Z., \& Zafar, S. (2010). The effects of anxiety on cognitive processing in English language learning. English Language Teaching, 3(2), 200-209.

Ahmad Khan, Z., \& Zafar, S. (2010). The effects of anxiety on cognitive processing in English language learning. English Language Teaching, 3(2), 200-209.

Aida, Y. (1994). Examination of Horwitz, Horwitz and Cope's construct of foreign language anxiety: The case of students of Japanese. Modern Language Journal, 78(2), 155-168.

Baker, W., \& Boonkit, K. (2004). Learning strategies in reading and writing: EAP contexts. Regional Language Centre Journal, 35(3), 299-328. https://doi.org/10.1177/0033688205052143

Brantmeier, C. (2002). Second language reading strategy research at the secondary and university levels: Variations, disparities, and generalizability. The Reading Matrix, 2(3), 1-14.

Brown, H.D. (2000). Principles of language learning and teaching. New York: Addison Wesley Longman.

Casdado, M. A., \& Dereshiwsky, M. I. (2004). Effect of educational strategies on anxiety in the second language classroom: An exploratory comparative study between U.S. and Spanish first-semester university students. College Student Journal, 38(1), 23-35.

Chamot, A. U. (1990). Learning strategies in second language acquisition. Cambridge: Cambridge University Press.

Chamot, A. U. (2005). Language learning strategy instruction: Current issues and research. Annual Review of Applied Linguistics, 25, 112-130.

Cohen, A. (1990). Language learning: Insights for learners, teachers, and researchers. Boston: Heinle \& Heinle Publishers. 
Cohen, A. D., Weaver, S. J., \&Li, T. Y. (1998). The impact of strategies-based instruction on speaking a foreign language. In A. D. Cohen (Ed.), Strategies in learning and using a second language (pp. 107-156). Harlow, England: Longman.

Ediger, M. (2002). The psychology of reading instruction. Reading Improvement, 41(3), 157-164.

Ellis, R. (1994). The study of second language acquisition. Oxford, England: Oxford University Press.

Gardner, R. C. (1985). Social psychology and second language learning: The role of attitudesand motivation. London: Edward Arnold.

Goodman, K., (1994). Reading, Writing, and Written Texts: A Transactional Sociolinguistic View. In R.B. Ruddell, M.R. Ruddell, \& H. Singer (eds.), Theoretical models and processes of reading. Newark, DE: International Reading Association.

Harris, T. L., \& Hodges, R. E. (Eds.). (1995). The literacy dictionary: The vocabulary ofreading and writing. Newark, DE: International Reading Association.

Horwitz, E. K. (1986). Preliminary evidence for the reliability and validity of a foreign-language anxiety scale. TESOL Quarterly, 20(3), 559-562. https://doi.org/10.2307/3586302

Horwitz, E. K. (2001). Language anxiety and achievement. Annual Review of AppliedLinguistics, 21,112 - 126.

Horwitz, E. K., \& Young, D. (1991). Language anxiety: From theory and research to Horwitz, E. K. (1991). Preliminary evidence for the reliability and validity of a foreign language anxiety scale. In E. K.

Horwitz, E. K., Horwitz, M. B., \& Cope, J. A. (1986). Foreign language classroom anxiety. The Modern Language Journal, 70(2), 125-132. http://dx.doi.org/10.2307/327317

Huang, H.-C., Chern, C.-L., \& Lin, C.-C. (2009). EFL learners' use of online reading strategies and comprehension of texts: An exploratory study. Computers \& Education, 52(1), 1326. http://dx.doi.org/10.1016/j.compedu.2008.06.003

Janzen, J. (2003). Developing strategic readers in elementary school. Reading Psychology, 24(1), 25-55. https://doi.org/10.1080/02702710308235

Kuru-Gonen, I. (2015). The relationship between FL reading strategies and FL reading proficiency: A study on Turkish EFL learners. Academic Journals. 10(24), 2924-2936.Retrieved from http://www.academicjournals.org/ERR

Lee, C. (2001). Is October Brown Chinese? A cultural modeling activity system for underachieving students. American Educational Research Journal, 38(1), 97-141.

Lien, H. Y. (2011). EFL learners" reading strategy use in relation to reading anxiety. Language Education in Asia, 2(2),199-212. Retrieved from http://camtesol.org/Download/LEIA

MacIntyre, P. D., \& Gardner, R. C. (1989). Anxiety and second-language learning: Toward a theoretical clarification. Language Learning, 39(2), 251-275.

MacIntyre, P. D., \& Gardner, R. C. (1991b). Investigating language class anxiety using the focused essay technique. The Modern Language Journal, 75, 296-304.

MacIntyre, P. D., \& Gardner, R. C. (1991c). Methods and results in the study of foreign language anxiety: A review of the literature. Language Learning, 41, 85-117.

MacIntyre, P. D., \& Gardner, R. C. (1993). On the measurement of affective variables in second language learning. Language Learning, 43, 157-194.

May, F. B. (2001). Unraveling the seven myths of reading. Boston, MA: Allyn and Bacon.

Mikulecky, B. S. (2008). Teaching reading in a second language. London: Pearson.

Mukminin, A., Ali, Rd. M., \& Fadloan, M.J. (2015). Voices from Within: Student Teachers' Experiences in English Academic Writing Socialization at One Indonesian Teacher Training Program. The Qualitative Report, 20 (9), 1394-1 
Mukminin, A., Muazza, Hustarna, \& Sari, S.R. (2015). Stories from the frontlines: In-service teachers' demotivating factors and policy recommendations. International Journal of Academic Research in Education, 1(2), 4052. DOI: $10.17985 /$ ijare.56085

Mukminin, A., Noprival, Masbirorotni, Sutarno, Arif, N., \& Maimunah. (2015). EFL Speaking Anxiety among Senior High School Students and Policy Recommendations. Journal of Education and Learning, 9 (3), 217 225-407.

O'Malley, J. M.\& Chamot, A. U. (1990). Learning strategies in second language acquisition. Cambridge: Cambridge University Press.

Oxford, R. L. (1990). Language learning strategies: What every teacher should know. New York: Newbury House.

Oxford, R. L. (1990). Language learning strategies: What every teacher should know. New York: Newbury House Publishers.

Rachman, S. (2004). Anxiety (2d ed.). New York, NY: Psychology Press.

Saito, Y., \& Samimy, K. K. (1996). Foreign language anxiety and language performance: a study of learner anxiety in beginning, intermediate, and advanced-level college students of Japanese. Foreign Language Annals, 29, 239-251.

Saito, Y., Horwitz, E. K., \& Garza, T. J. (1999). Foreign language reading anxiety. The Modern Language Journal,83(2), 202-218. http://dx.doi.org/10.1111/0026-7902.00016

Samimy, K. K., \& Tabuse, M. (1992). Affective variables and a less commonly taught language: A study in beginning Japanese Classes. Language Learning, 42, 377-398.

Sanchez-Herrero, S. A., \& Sanchez, M. D. P. (1992). The predictive validation of an instrument designed to measure student anxiety in learning a foreign language. Education and Psychological Measurement, 52(4), 961-966. https://doi.org/10.1177/0013164492052004019

Sellers, V. (2000). Anxiety and reading comprehension in Spanish as a foreign language. Foreign Language Annals, 33(5), 512-521. http://dx.doi.org/10.1111/j.1944-9720.2000.tb01995x

Sharma, K. L., \& Gandhi, N. (1971). Hierarchy and among of Fear in Low and High Anxious groups of Students. Indian Psychological Review, 8, 29-30.

Sharma, K. L., \& Gandhi, N. (1971). Hierarchy and among of Fear in Low and High Anxious groups of Students. Indian Psychological Review, 8, 29-30.

Sheorey, R., \& Mokhtari, K. (2001). Coping with academic materials: Differences in the strategies of native and nonnative readers. System: An International Journal of Educational Technology and Applied Linguistics, 29, 431- 449. https://doi.org/10.1016/S0346-251X(01)00039-2

Sheorey, R., \& Mokhtari, K. (2001). Differences in the metacognitive awareness of reading strategies among native and non-native readers. System,29(4), 431-449. http://dx.doi.org/10.1016/S0346-251X(01)00039-2

Shi, Y. Z., \& Liu, Z. Q. (2006). Foreign language reading anxiety and its relationship to English achievement and gender. Journal of PLA University of Foreign Languages, 29(4), 59-65.

Spielberger, C. D. (1983). Manual for the state-trait anxiety inventory. Palo Alto, CA: Consulting Psychologists Press.

Tsai, C. C. (2013). Exploring the relationships between reading anxiety and reading strategy use among university students in Taiwan. International Journal of English and Education, 2(4),20-39. Retrieved from www.ijee.com

Walker, J. B. (2000). Diagnostic teaching of reading: Techniques for instruction and assessment (4th ed.). Columbus: OH: Merril.

Wenden, A. (1991). Learner strategies for learner autonomy. Englewood Cliffs, NJ: Prentice- Hall. 
Yamashita, J. (2004). Reading attitudes in L1 and L2, and their influence on L2 extensive reading. Reading in a Foreign Language, 16(1), 1-17.

Yang, X, L. (2006). Motivation and reading strategies. Sino-US English Teaching, 6(12), 37-40

Zare, P. (2013). Exploring reading strategy use and reading comprehension success among EFL learners. World Applied Sciences Journal, 22(11), 1566-1571.

Zhang, L.J. (2000). Uncovering Chinese ESL students' reading anxiety in a study-abroad context. Asia Pacific Journal of Language in Education, 3(2), 31-56. 